\title{
Classification System of Crimes in Criminal Code of the Republic of Uzbekistan
}

\author{
Nargizakhon Rakhimjonovna Rakhimjonova
}

Lecturer, Department of Criminal Law, Criminology and Fight against Corruption, of Tashkent State University of Law

\section{ABSTRACT}

For many years, the issue of classification of crimes has been in the focus of attention of legal professionals, in particular, legal scholars, experts, law enforcement agencies. The reason is that it is through the classification of crimes that a socially dangerous act committed can be punished and the purpose of the punishment can be achieved. The system of classification of crimes is a list of crimes provided for in the Criminal Code, arranged in a certain order, depending on the severity of the crime. This article illustrates classification system of crimes according to the Criminal Code of the Republic of Uzbekistan. There are given essential statistics on each type of crime and the importance of classification system of crimes in applying the norms of General Part of the Criminal Code of Uzbekistan.

Keywords: Criminal Code, structural, comparative legal, logical, exact sociological, less serious crimes, serious crimes.

Article Received: 10 August 2020, Revised: 25 October 2020, Accepted: 18 November 2020

\section{Introduction}

Indeed, systematization works well in the study of a particular field. By systematizing, an object can be not only quickly and easily studied, but mastered.

Classification is a Latin word (classic-degree, fasio-do) is the distribution of objects, events and concepts by class, section, degree according to their general characteristics.

Classification is the first and most important step that a researcher must take for any huge and diverse group of events[1]. Classification as a method of study has two meanings for the researcher: externally, it is a method that incorporates system and order into research, while internally, it is a method that predetermines the completeness and accuracy of research results[2].

Classification is one of the ways to know the phenomena of nature and society[3], as well as a way to solve problems in this or that practical activity of man.

Systematization of the studied objects, their division into parts, groups, should be carried out without losing interdependence. Whether it is possible to understand the whole from the part even by dividing the whole into parts, or vice versa. By studying in this way, it will be possible to study the object in more depth[4].

The Criminal Code of the Republic of Uzbekistan is a systematic legal document. A natural classification method was used to systematize it. First of all, this Code is divided into two parts: General and Special.

The General Part of the Criminal Code consists of the general rules and principles of criminal law and deals with two basic concepts, which are the concepts of crime and punishment[5]. The law defines the tasks and principles of the Criminal Code, the application of the criminal law by region and time, the grounds for criminal liability, guilt and its forms, the age of criminal liability and the scope of persons subject to prosecution, the exception to criminality, the purpose of punishment and each criminal penalty. system, imposition of criminal liability and 
punishment, exemption from liability or punishment, liability of minors, and medical coercive measures.

The Special Part of the Criminal Code defines specific crimes and the penalties imposed for the commission of these crimes. Although criminal law consists of two parts, these parts are not separate independent branches of law, they form a single whole criminal law, which is closely connected with each other. Their uniqueness lies in the unity of their functions and the fact that one cannot exist without the other[6].

There are a number of classification methods. Including:

- the articles of the Special Part of the Criminal Code are classified according to the nature and level of social danger (crimes with low social risk, less serious crimes, serious crimes, very serious crimes);

- as well as classification by object (crimes against the person, crimes against peace and security, crimes in the field of economics, etc.);

- classification according to the structure of the objective party (crimes of material and formal content);

- subjective classification (crimes committed intentionally or negligently);

- classification by subject (age criteria, specific subject characteristics).

However, when it comes to the classification of crimes, legal scholars cite two types based on the current legislation[7]:

- classification of crimes by object;

- classification of crimes according to social danger.

\section{Methodology}

Historical, structural, comparative legal, logical, exact sociological, complex research of scientific sources, induction and deduction, and statistical data analysis were used in the research.

\section{Main Part}

The system of classification of crimes is a list of crimes provided for in the Criminal Code, arranged in a certain order, depending on the severity of the crime. According to the criminal law of the Republic of Uzbekistan, the system of classification of crimes consists of crimes with low social risk, less serious crimes, serious crimes and very serious crimes[8].

\section{Crimes with low social risk.}

The table in which the articles of the Special Part of the Criminal Code, classified by the degree of social risk of crimes, contains 587 general descriptions of crimes, of which 259 are crimes of low social risk. This is $\mathbf{4 4 . 1 \%}$ of the total number of crimes.

Crimes with low social risk are present in all sections of the Special Part of the Criminal Code. In fact, Article 156, Part 1, and Article 163, Part 1 of the chapter of "Crimes against the Peace and Security of Humanity", which consists despite mainly of serious and very serious crimes, also define crimes with low social risk.

In $\mathbf{1 0 3}$ of the crimes with low social risk, or $\mathbf{1 7 . 5 \%}$, non-custodial sentences were provided. Also, for crimes crimes with low social risk, only $\mathbf{2}$ articles provide for deprivation of liberty, while the remaining 154 provide an alternative type of punishment.

However, in Article 15 of the Criminal Code, the distinction between nonsocially dangerous crimes is related not only to the nature and degree of their social danger, but also to the sentence of deprivation of liberty imposed. It should be noted that the sanction of the Special Part of the Criminal Code provides not only for deprivation of liberty for these crimes, but also for the most severe of the alternative punishments[9].

In our view, this practice not only provides relief to the perpetrator, but also saves the state budget spent on the material support of prisoners. 
In our opinion, the application of this experience to our national legislation is expedient from a humanitarian point of view.

In addition, in Address of President of the Republic of Uzbekistan Shavkat Mirziyoyev to the Oliy Majlis, stressed the need to reconsider the terms of criminal prosecution based on the age-old values of our people, such as forgiveness and tolerance[10].

Based on the above, we propose to amend the second part of Article 15 of the Criminal Code as follows:

"Crimes with low risk are the crimes committed intentionally and are punishable by deprivation of liberty for a term not exceeding two years as the most severe punishment, as well as by negligence for a term not exceeding five years as the most severe punishment, shall be punishable by deprivation of liberty for a term not exceeding five years."

\section{Less serious crimes.}

Part 3 of Article 15 of the Criminal Code of the Republic of Uzbekistan stipulates that less serious crimes are crimes committed intentionally and punishable by deprivation of liberty for a term of more than three years, but not more than five years, as well as by negligence and deprivation of liberty for more than five years.

The Law of the Republic of Uzbekistan "On Amendments and Addenda to the Criminal, Criminal Procedure Codes and the Code of Administrative Liability of the Republic of Uzbekistan in connection with the liberalization of criminal penalties" of August 29, 2001 changed less serious crimes to the above edition.

According to the amendment on September 22, 1994, negligent crimes were considered less serious crimes and did not specify a specific term of deprivation of liberty. The previous version also included less serious crimes, which were punishable by up to five years deprivation of liberty, but the new version now includes crimes punishable by three to five years deprivation of liberty. This has led to a number of less serious crimes spontaneously shifting to the category of crimes with low social risk[11].

It should be noted that $\mathbf{1 5 1}$ of the norms of the Special Part of the Criminal Code, or $\mathbf{3 3 . 7 \%}$, correspond to less serious crimes.

Less serious crimes are found in all sections of the Special Part of the Criminal Code. In almost all articles of the chapters "Crimes against the family, youth and morals", "Looting others property", "Crimes against the fundamentals of economics", "Crimes in the field of economic activity", "Crimes against governance", "Crimes against justice" there are less serious crimes.

There are 27 or $\mathbf{6 . 3 \%}$ less serious crimes of the Special Part of the Criminal Code provides only deprivation of liberty, and for 124 or $93.6 \%$ articles provides alternative punishment.

In the analysis of less serious crimes, we see that according to Article 15 of the Criminal Code, the terms of deprivation of liberty for intent and negligence are set differently[12].

This rule is also enshrined in the Criminal Code of Armenia[13], Kazakhstan[14], Kyrgyzstan[15], Russia[16] and Tajikistan[17]. According to the CIS Model Criminal Code, for the intentional commission of less serious crimes in these countries - up to 5 years deprivation of liberty.

In our view, this is logically correct because intentional crime is more socially dangerous than reckless crime.

However, the Criminal Code of Azerbaijan[18], Georgia[19], Moldova[20], Turkmenistan[21], and Ukraine[22] stipulates the same term of deprivation of liberty for intentional and negligent commission of less serious crimes.

For example, in the Criminal Code of Azerbaijan - deprivation of liberty for up to 7 years, in the Criminal Code of Georgia - 
up to 5 years, in the Criminal Code of Moldova - up to 5 years(although there are forms of both guilt: intention and negligent in their CC), in the Criminal Code of Ukraine - up to 5 years.

In our view, the failure to take into account the form of guilt in sentencing a crime in law leads to a lack of fair punishment for the person's actions. The introduction of the concept of guilt in criminal law is directly reflected in the individualization of punishment and the differentiation of liability.

It should also be noted that the Criminal Code contains norms establishing deprivation of liberty for 8 to 12 years for the consequence of negligence as a result of a crime (Article 297 Part 3). Although the form of guilt in the act was negligence, the amount of punishment increased depending on the consequence (death of people). In addition to studying foreign experience, we have seen that in particular, Article 46 of the Criminal Code of Kazakhstan stipulates that the amount of deprivation of liberty for negligent crime should not exceed 10 years.

In our opinion, it is expedient to implement this norm in domestic legislation. As a result, it is possible to reduce the number of unreasonably set years and to put less serious crimes into a certain pattern.

We also consider it appropriate to increase the term of deprivation of liberty for intentional commission of less serious crimes to more than two years, as we have proposed to set the maximum sentence of deprivation of liberty for intentional commission of less serious crimes - two years. Therefore, it is proposed to amend Article 15, Part 3 in the following wording:

"Less serious crimes are crimes committed intentionally and are punishable by deprivation of liberty for a term exceeding two years but not exceeding five years, as well as committed by negligence and are punishable by deprivation of liberty for more than five years and not exceeding ten years as the most severe punishment".

Exemption from liability and punishment provided for in the Criminal Code in respect of a person who has committed such crimes shall be subject to certain conditions in the application of the norms[12].

In particular, Article 66 of the Criminal Code of the Republic of Uzbekistan stipulates that a person who has committed crimes with low social risk and less serious crimes for the first time shall be held liable if he voluntarily remedied the damage caused by the crime and sincerely confessed his guilt provided that it may be released from liability. Hence, this rule applies only to the above categories.

The application of Article 71 of the Criminal Code of the Republic of Uzbekistan (release of the perpetrator from punishment on the grounds of sincere remorse) also provides for this category of crimes.

Pursuant to Article 73 of the Criminal Code of the Republic of Uzbekistan, a person may be released on parole after serving at least one third of the sentence imposed by a court for crimes with low social risk and less serious crimes.

According to Article 74 of the Criminal Code of the Republic of Uzbekistan, for at least a quarter of the sentence imposed by a court for crimes with low social risk or less serious crimes, the remainder of the sentence may be commuted to a lighter sentence.

It is also stipulated that if a person is sentenced to deprivation of liberty for a crime with low social risk, the sentence shall be served in a penal colony (Article 50 of the Criminal Code of the Republic of Uzbekistan).

In addition, the commission of this type of crime by minors is punishable by deprivation of liberty (Article 85), release from liability or punishment by coercive measures (Article 87), parole (Article 89), in replacing the sentence with a lighter one (Article 90). 


\section{Serious crimes}

The fourth part of Article 15 of the Criminal Code of the Republic of Uzbekistan stipulates that serious crimes are committed intentionally and are punishable by imprisonment for a term exceeding five years, but not more than ten years. In contrast to the above two categories of crimes, serious crimes are committed only intentionally.

There are 114 or $19.4 \%$ of the norms of the Special Part of the Criminal Code constitute serious crimes. Of these, depriviation of liberty is sentenced to $\mathbf{1 0 1}$ or $\mathbf{8 8 . 5 \%}$ norms, and alternative punishment to 13 or $11.4 \%$ norms.

Serious crimes are mainly seen in the chapters of "Crimes against the fundamentals of economics", "Crimes related to obstruction of business activity, unlawful interference and other offenses that infringe the rights and legitimate interests of business entities", "Crimes against public order", "Crimes against justice".

Following amendments and additions to the Law of August 29, 2001, Article 15 of the Criminal Code of the Republic of Uzbekistan adopted new rules for the classification of crimes according to the level of social danger. (Part 3, Article 104, Part 4, Article 167, Part 3, Article 186, Part 3, Article 283, Part 3, Article 297).

The main criterion in classifying a crime as a felony is the length of the sentence specified in the sanction of the article determining the liability for a particular crime[13]. The legislature took into account the nature of the damage caused by the crime, the method of committing the crime, whether the crime was committed only through intentional guilt, whether the crime was committed for malicious or other malicious purposes, the importance of the object of aggression, the identity of the perpetrator and other circumstances.

In our view, the legislature has taken the social danger of the act as the main criterion in the detection of serious crimes.
Because, if we pay attention, the majority of serious crimes are aggravated crimes, which is assessed by the high social risk of spontaneous action. For example, the recognition of serious crimes in the chapter "Looting others property" is influenced by the fact that the act was committed in large numbers, by a very dangerous recidivist, by an organized group or in its interests.

When it comes to serious crimes in criminal law, it should be noted that the legislature provided for alternative punishments for a number of intentional serious crimes.

In particular, Article $186^{1}$, Part 2, Article $186^{2}$, Part 2, Article $188^{1}$, Part 2, Article $192^{2}$, Part 3, Article 192 ${ }^{3}$, Part 3, Article $192^{9}$, Part 5, referred to in the chapter of "Crimes in the Sphere of Economic Activity" fines are imposed in conjunction with deprivation of liberty and other penalties, although parts are considered aggravated and committed in aggravating circumstances (in large numbers, by a group of individuals with prior conspiracy, repeatedly or by a dangerous recidivist).

In our opinion, fines should not be imposed for serious and very serious crimes. Because with such a concession, injustice can be tolerated towards victims of serious or very serious crimes. In addition, the principles of the Criminal Code, including the principle of fairness, which states that the punishment or other legal measure applied to a person guilty of a crime must be fair, ie in accordance with the gravity of the crime, the degree of guilt and social danger of the person.

For serious crimes, the law does not provide the same privileges as for the above two categories of offenses, however, privileges are applied under certain conditions such as in parole, commutation of sentence, as well as the responsibility of juveniles, and in replacing the sentence with a lighter one . 
Based on the above proposal, we propose to state Part 4 of Article 15 of the Criminal Code as follows:

"Serious crimes are intentional and are punishable by imprisonment for a term not exceeding five years, but not more than ten years.

\section{Extremely serious crimes.}

According to part 5 of Article 15 of the Criminal Code, the most serious crimes are intentional crimes punishable by deprivation of liberty for a term exceeding ten years or life imprisonment.

As mentioned above, in connection with the liberalization of criminal penalties, the Law of the Republic of Uzbekistan "On Amendments and Addenda to the Criminal, Criminal Procedure Codes and the Code of Administrative Liability" of August 29, 2001 introduced a number of amendments to the Criminal Code. Due to the fact that the most serious crimes in a number of articles were transferred to the category of serious crimes, the number of very serious crimes in the current Criminal Code has significantly decreased. Currently, 63 or $10.7 \%$ of the total number of crimes are serious crimes, of which 62 or $98.4 \%$ are sentenced to deprivation of liberty, and 1 or $1.5 \%$ are punishable by alternative punishment.

Serious crimes are included in the chapters of Special Part of the Criminal Code of "Crimes against sexual freedom", "Crimes against peace and security of humanity", "Looting of property", "Crimes against the order of obedience and military honor", "Against the order of military service". In our opinion, this is related to the value of the object of the offenses in this chapter.

\section{Results and Discussion}

The Penal Code provides for deprivation of liberty for all very serious crimes, and there are no alternative punishments[14]. In our opinion, this is the right practice, because very serious crimes are different from other crimes with high social risk and the importance of the object that has been damaged or is at risk of damage.

The penalty of life imprisonment is provided for in only two articles: intentional homicide in aggravating circumstances (part 2 of Article 97) and terrorism (part 3 of Article 155).

The legal significance of very serious crimes is that the rules of exemption from liability and punishment apply to a person who has committed this type of crime in a limited way. In particular, in connection with the expiration of the period of prosecution under Article 64 of the Criminal Code, a person shall be released from liability if fourteen years have elapsed from the date of the commission of a very serious crime.

Exemption from liability under Articles $65,66,66^{1}$ of the Criminal Code does not apply.

Also, exemption from punishment under Article 71 of the Criminal Code of the Republic of Uzbekistan does not apply.

In the case of a very serious crime, probation under Article 72 of the Criminal Code does not apply (except for minors, women, persons over sixty years of age).

A lighter sentence may be applied to a person who has committed a very serious crime only after at least half of the sentence imposed by the court has actually been served[15].

Thus, it can be said that the classification of crimes according to their nature and level of social danger is important in the implementation of certain norms of the General Part of the Criminal Code. What category of crime the perpetrator committed directly affects his or her subsequent fatep[16].

\section{Conclusion}

The study of foreign experience has shown that in a number of countries, including Azerbaijan, Armenia, Belarus, Kazakhstan, Moldova, Tajikistan, Turkmenistan, the Criminal Code of the Republic of Ukraine, crimes with low social 
danger are the crimes committed intentionally and are punishable by deprivation of liberty for a term not exceeding two years as the most severe punishment.

The application of this positive experience in our legislation will lead to the humanization [17] of criminal law, ensuring effective and reliable protection of the rights and freedoms of citizens, improving the system of criminal liability and punishment.

The sanction of the Special Part of the Criminal Code provides for other alternative punishments in addition to imprisonment. In such cases, the most severe punishment is imprisonment. Therefore, the classification of crimes should be based on the duration and amount of the most severe punishment, and should be supplemented with "as the most severe punishment."

It is proposed to state part 3 of Article 15 of the Criminal Code in the following wording:

"Less serious crimes are crimes committed intentionally and are punishable by deprivation of liberty for a term exceeding two years but not exceeding five years, as well as committed by negligence and are punishable by deprivation of liberty for more than five years and not exceeding ten years as the most severe punishment".

4. Article 15 of the current Criminal Code does not provide for the maximum penalty of deprivation of liberty for the commission of less serious crimes as a result of negligence.

As a result of the analysis of the norms of the Special Part of the Criminal Code, we saw that there are articles that are committed as a result of negligence and are punishable by deprivation of liberty for a term of eight to twelve years (Article 297 Part 3 of the CC).

In addition to studying foreign experience, we have seen that, in particular, Article 46 of the Criminal Code of Kazakhstan stipulates that the amount of imprisonment for negligent crime should not exceed ten years.

In our opinion, Article 15 of the Criminal Code of the Republic of Uzbekistan, implementing this norm in national legislation

It is proposed to state Part 4 in the following wording:

"Less serious crimes are crimes committed intentionally and are punishable by deprivation of liberty for a term exceeding two years but not exceeding five years, as well as committed by negligence and are punishable by deprivation of liberty for more than five years and not exceeding ten years as the most severe punishment"

In connection with the introduction of this norm, there is a need to revise the amount of punishment for negligent crimes in the Special Part of the Criminal Code and bring it into line with this classification.

5. Article 15 of the Criminal Code of the Republic of Uzbekistan

It is proposed to state sections 5 and 6 in the following edition:

"Serious crimes are intentional and are punishable by deprivation of liberty for a term not exceeding five years, but not more than ten years as the most severe punishment.

"Very serious crimes include those committed intentionally and are punishable by up to ten years' deprivation of liberty or life imprisonment".

\section{References}

[1] X.Ochilov, D.Kamalova, Criminal responsibility for inchoate Offence according criminal code of the republic of Uzbekistan. Tashkent State University of Law, Republic of Uzbekistan, International Journal of Advanced Science and Technology, Vol. 29, No. 5, (2020), pp. 1729-1737.

[2] Salaev.N. (2017) "Differentiation, individualization, execution of criminal punishments and its goals: way to success," Review of law sciences: Vol. 1: 
Iss. 1 , Article25.

[3] S.S.Niyozova. Prevention of Crime in the Family and the Role of Victimology in the Republic of Uzbekistan. International Journal of Advanced Science and Technology Vol. 29, No. 3, (2020), pp. 3962.

[4] Tadjibaeva A. The role of a lawyer in ensuring the protective function of the Republic of Uzbekistan in criminal proceedings. European Journal of Molecular \& Clinical Medicine ISSN 25158260 Volume 7, Issue 2, 2020. pp.21622168

https://ejmcm.com/article 2434.html

[5] Xudaykulov.F.X. Extreme cruelty is as the way of committing crime of murder: theoretical-practical problems and their solutions. // European Journal of Research. https://journalofresearch.info/ Vienna, Austria. 2019. Volume 4, Issue 10. - P.8-11. (Impact factor (SJIF: 6.054, IFS 3,8. UIF 2.7)

[6] Altiyev R.S. Matters of liability for fraud in the field of credit in the Republic of Uzbekistan. International Journal of Research, Volume 07, Issue 04, 2020. pp.619-622

[7] Abzalova K. M. et al. Some matters of imposition of punishment for preparation for premeditated murder in the criminal code of the Republic of Uzbekistan //International Journal of Legal Studies (IJOLS). - 2018. - T. 4. - №. 2. - C. 159167.

[8] Fazilov. F.M. The general concept of legalization of revenue from criminal activities ISJ Theoretical \& Applied Science, 11 (79), 255-259. http://tscience.org/arxivDOI/2019/11-79/PDF/1179-54.pdf https://elibrary.ru/item.asp?id=42407736

[9] Xaydarov Sh. D. 12-25-2018 Measures of preventing crime of nonperformance of one's duties in their profession

https://core.ac.uk/download/pdf/285996616 .pdf
[10] Hojiyev. N.K. Liability For Aggression Against Human Health. International Journal of Pharmaceutical Research | Jan - Mar 2020 | Vol 12 Issue 2530-2535. 1

http://www.ijpronline.com/ViewArticleDet ail.aspx?ID=19039

[11] S.Kodiraliev. Peculiarities of the introduction of modern information and communication technologies in the courts. Odillik mezoni. №-11, 2020. pp.18-20.

[12] https://www.legislationline.org/doc uments/section/criminalcodes/country/55/Uzbekistan/show

[13] https://www.legislationline.org/doc uments/section/criminalcodes/country/45/Armenia/show

[14] https://www.legislationline.org/doc uments/section/criminal-

codes/country/21/Kazakhstan/show

[15] https://www.legislationline.org/doc uments/section/criminal-

codes/country/20/Kyrgyzstan/show

[16] https://www.legislationline.org/doc uments/section/criminal-

codes/country/7/Russian $\% 20$ Federation/sho $\underline{\mathrm{W}}$

[17] https://www.legislationline.org/doc uments/section/criminalcodes/country/49/Tajikistan/show

[18] https://www.legislationline.org/doc uments/section/criminal-

codes/country/43/Azerbaijan/show

[19] https://www.legislationline.org/doc uments/section/criminalcodes/country/29/G eorgia/show

[20] https://www.legislationline.org/doc uments/section/criminal-

codes/country/14/Moldova/show

[21] https://www.legislationline.org/doc uments/section/criminal-

codes/country/51/Turkmenistan/show

[22] https://www.legislationline.org/doc uments/section/criminal-

codes/country/52/Ukraine/show 